\title{
A Study on Competitiveness Assessment Indicators for Global Aviation Training Organizations
}

\author{
Yong $\mathrm{Ki} \mathrm{Yi}^{1}$, Kwang-Eui $\mathrm{Yoo}^{2}$ \\ ${ }^{1}$ Researcher, Korea Aerospace University, 76 Hanggongdaehak-ro, Deogyang-gu, Goyang-City, South Korea \\ ${ }^{2}$ Professor, Korea Aerospace University, 76 Hanggongdaehak-ro, Deogyang-gu, Goyang-City, South Korea \\ Corresponding Author: Kwang-Eui Yoo, Professor, Korea Aerospace University, 76 Hanggongdaehak-ro, Deogyang-gu, \\ Goyang-City, South Korea. E-mail: keyoo@kau.ac.kr
}

Received: April 21, 2018

doi:10.11114/jets.v6i8.3373
Accepted: June 14, $2018 \quad$ Online Published: June 19, 2018

URL: https://doi.org/10.11114/jets.v6i8.3373

\begin{abstract}
This study aims to develop a competitiveness assessment index for global aviation training organizations. The study utilizes the four factors of the Diamond model developed by Michael Porter. To select candidate indices, expert consultations were made, and two stages of Delphi survey were conducted on 24 experts in the area of global aviation training and education. Finally, 19 indices were selected for analysis. In order to assess the reliability of the final indices and justify selection, an empirical study was conducted with 100 participants, yielding statistically significant results. The 19 indices were organized into a three-level hierarchy system, and an analytical hierarchy process (AHP) was conducted to evaluate the importance of each index. The results of the AHP indicated that 'quality of instructors' was the most important index, followed by 'feedback from trainees for the course (level of satisfaction with the course)' and 'director's management skills and leadership'. This study will contribute to enhancing the competitiveness of global aviation training organizations.
\end{abstract}

Keywords: competiveness, competiveness assessment indicator, aviation training organization, Delphi, Analytic Hierarchy Process (AHP), Diamond model, Content Validity Ratio (CVR), Coefficient of Variation (CV)

\section{Introduction}

The world has entered an era of limitless competition, and the field of training is no exception. Training and education service areas (e.g. universities) as well as aviation training organizations compete fiercely to survive. Aviation training organizations in particular, aggressively seek out methods of enhancing their competitive power in the global aviation training market. For instance, they attempt to attract competitive, highly qualified instructors to develop and deliver courses. In this regard, studies on how to measure competitive power of global aviation training organizations to survive and gain competitive advantage are of vital significance.

This study aims to explore the implications of competitiveness assessment indices in evaluation of aviation training organizations in order to conceptualize competitiveness of global aviation training organizations.

With that in mind, in order to research theoretical aspects on competition and establish criteria on competitiveness assessment for global aviation training organizations, literature and precedent studied were reviewed. Since studies on global aviation training competitiveness do not exist, studies on completion assessment for higher education institutions were mainly reviewed.

This study endeavors to develop competitiveness assessment criteria and indices optimized for global aviation training organizations using statistical analysis associated with competitiveness assessment theory. To accomplish this objective, this study attempts to collect and empirically analyze expert opinions in the field of aviation personnel training.

\section{Research Methodology}

Competitiveness assessment for this study is carried out on the basis of Michael Porter's Diamond theory. The hierarchy structure and weighted value of assessment indices are analyzed via an analytic hierarchy process (AHP), and the Delphi survey is used to collect expert opinions. A brief instruction of each method is as follows.

\subsection{Diamond Theory}


Diverse theoretical approaches to competitiveness assessment have been introduced. Among those approaches, the Diamond model offered by Professor Michael Porter (1990) at Harvard University has become the most representative. This study aims to draw all relevant variables for the competitiveness assessment of global training organizations on the basis of the four key elements from Michael Porter's Diamond framework - (1) factor conditions, (2) demand conditions, (3) related and supporting industries, and (4) firm strategy, structure and rivalry. The Diamond framework was originally designed to analyze national competitiveness. However, because it can be applied to various industries, enterprises and numerous non-business areas, it has been used as a basic model to effectively assess the competitiveness of global aviation training organizations.

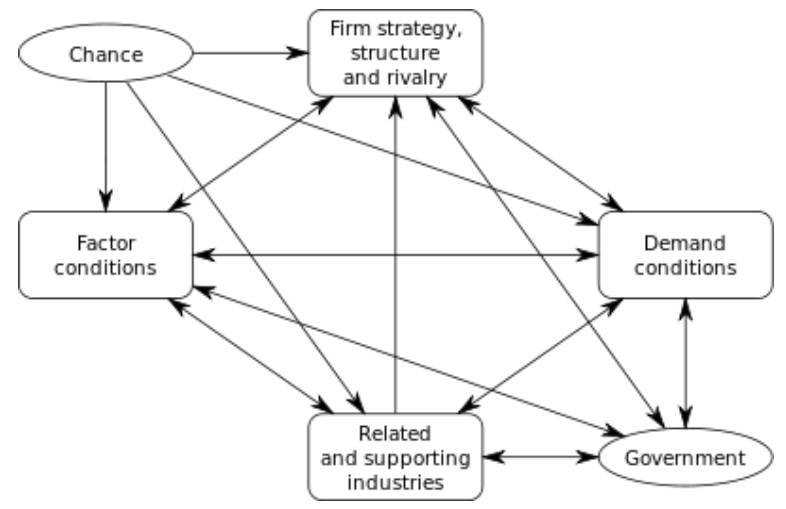

Figure 1. Diamond Model

In the Diamond model, factor conditions is a comprehensive concept that includes social overhead capital such as natural resources, manpower, capital, technology status, roads, ports, airports and telecommunication facilities. Demand conditions is the demand size and quality. Firm strategy, structure and rivalry can potentially affect national competitiveness in terms of economic and business environments and strong competitors which are closely related to creation, structure and operation of firms. The development and growth of related local supporting industries and suppliers can become key competitiveness assessment indicators as these industries directly complement each other in the overall national economy.

\subsection{Delphi}

In the event of insufficient precedent research and literature, a Delphi survey can be carried out on a panel of experts in corresponding area. Until the opinions of experts converge to an agreement, rounds of a basic survey method is performed until a criteria can be justified from the survey responses. A criterion can be assumed to be justified if the responses from experts converge in a consistent pattern in terms of the level of convergence and agreement and the Kendall's coefficient of concordance (Kendall's W). The Delphi survey leads to a convergence in expert opinions via a formula that divides the difference between the upper quartile (Q3) and lower quartile (Q1) in half, thus (Q3-Q1)/2. The agreement level can be estimated using the difference between the quartiles and the median. This level varies from 0 to 1 , and a value closer to 1 would imply a higher level of agreement. The value of Kendall's W ranges from 0 to 1 . A Kendall's W value closer to 1 implies that the level of opinion convergence is high (Schmidt, 1997). The following formula represents the calculation of the Kendall's W value;

$$
\text { Kendall's } W=\frac{12 \sum_{j=1}^{m}\left(\sum_{i=1}^{n} R_{i j}\right)^{2}}{m^{2} n\left(n^{2}-1\right)}-\frac{3(n+1)}{n-1}
$$

where the total number of judges (respondents) in a group is ' $m$ ', the number of objects, ' $n$ ', regarding object ' $i$ ' ranked by judge ' $\mathrm{j}$ '.

The survey can be justified using the agreement level according to the content validity ratio (CVR). Lawshe (1975) indicated that when the panel number was 15 or 25 , the CVR had to be at least $0.49(\mathrm{P}=0.05)$ or $0.37(\mathrm{P}<0.05)$, respectively. Table 1 is to show index selection criteria. 
Table 1. Detailed Index Selection Criteria

\begin{tabular}{|c|c|c|}
\hline & Contents & Criteria \\
\hline $\begin{array}{l}\text { Content Validity } \\
\text { Ratio (CVR) }\end{array}$ & $\begin{array}{l}\text { If the number of respondents answering } 4 \text { or } 5 \text { in a } 5 \text {-point Likert survey exceeds } 50 \% \text {, it is } \\
\text { deemed justified. }\end{array}$ & $\begin{array}{l}\mathrm{CVR} \geqq 0.37 \\
(\text { When the total panel } \\
\text { number exceeds } 25)\end{array}$ \\
\hline Level of Agreement & $\begin{array}{l}\text { As the difference between the } 3^{\text {rd }} \text { and } 1^{\text {st }} \text { quartile decreases, the value approaches } 1 \text {. As the } \\
\text { difference increases, the value approaches } 0 \text { and the level of agreement decreases. }\end{array}$ & $\begin{array}{l}\text { Level of Agreement } \geqq \\
0.75\end{array}$ \\
\hline $\begin{array}{l}\text { Level } \\
\text { Convergence }\end{array}$ & $\begin{array}{l}\text { As the difference between the } 3^{\text {rd }} \text { and } 1^{\text {st }} \text { quartile decreases, the level of convergence } \\
\text { increases. When the difference increases, the level of convergence decreases. }\end{array}$ & $\begin{array}{l}\text { Level of Convergence } \leqq \\
0.50\end{array}$ \\
\hline Positive Rate & $\begin{array}{l}\text { This is the percentage of respondents answering relatively positively (indicating } 4 \text { or } 5 \text { points } \\
\text { in a 5-point Likert survey). }\end{array}$ & More than $55 \%$ \\
\hline Average Value & $\begin{array}{l}\text { These are the average values of the positive answers in a 5-point Likert survey. } \\
\text { (The 5-point value in a } 7 \text { point Likert survey which is considered a positive- answer-value, is } \\
\text { converted to this value in a 5-point Likert survey.) }\end{array}$ & $\begin{array}{l}3.56 \\
\text { (5-point Likert survey) }\end{array}$ \\
\hline
\end{tabular}

$2.3 \mathrm{AHP}$

The analytic hierarchy process (AHP) was developed by Professor Thomas L. Saaty in the early 1970s and is also known as multi-criteria decision making (MCDM). It is a decision making method that applies knowledge, experience and intuition from respondents via pairwise comparisons between objects comprising each hierarchy level (Kim Yong-Jung, 2013). The AHP method is usually carried out in order to analyze the weight (significance level) of each individual subject after conducting a Delphi survey. The combination of Delphi and AHP is theoretically a justifiable survey(Lee Hwa Jin, 2011; Song Dal Yong, 2007; Cho Geun Tae, Cho Yong Gon \& Kang Hyun Soo, 2003).

The judgments (responses) from the respondents in an AHP survey must be verified for consistency using the consistency index (CI). The consistency ratio (CR) also demonstrates whether consistency of opinions has been maintained. Consistency is the reasoning of the replies from respondents, namely reliability. The CR utilizes

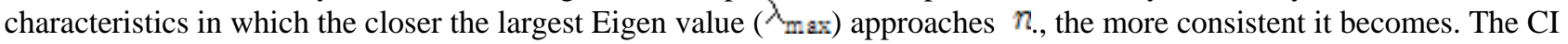
can be calculated using the following formula.

$$
C I=\frac{\lambda_{\max }-n}{n-1}, \quad \lambda_{\max }=\frac{1}{n} \sum_{a=1}^{f} \frac{\sum_{a=1}^{f} v_{b} \times r_{a b}}{v_{a}}
$$

There are two ways to synthesize the weight values of each hierarchy level. One is to calculate the values from a single paired comparison after collecting opinions from more than two respondents. The other is to add up the results after collecting a pairwise comparison matrix (Saaty, 1980). The latter is usually used. When adding up the results, organizing a single pairwise comparison after combining a geometric mean is the most desirable method (Cho Geun Tae et al. 2003).

This study synthesized the overall results via a pairwise comparison based on the AHP. To calculate the weight values $\left(r_{a b i}\right)$,the respective weight values had to be synthesized from the pairwise comparison matrix of each respondent $(n)$ as a geometric mean $\left(G M\left(r_{a b}\right)\right)$, and a single pairwise comparison matrix had to be organized. The formula is as follows.

$$
G M\left(r_{a b}\right)=\prod_{i=1}^{n} \sqrt[n]{r_{a b i}}=\prod_{i=1}^{n}\left(r_{a b i}\right)^{1 / n}
$$

\subsection{Delphi Analysis and Results}

The survey items for the Delphi were selected by literature review on competitiveness assessment indices for higher education institutions. In total, 62 indices for competitiveness assessment for global aviation training organizations were selected in four distinctive areas of Diamond theory, through literature research - 19 indices for factor conditions; nine indices for demand conditions; 18 indices for firm strategy, structure and rivalry; and 16 indices for related and supporting industries.

Subsequently, the first Delphi survey was carried out through a group of Delphi panelists who are composed of 24 experts selected at the area of internationally renowned aviation institute. The $2^{\text {nd }}$ Delphi survey was designed to encourage panelists to change or amend their opinions referring to an average value and a median value from opinions of panelists collected in the $1^{\text {st }}$ Delphi survey (Best, 1974).

The verification procedure was applied utilizing content validity ratio (CVR) (Lawshe, 1975). Because the coefficient of variation (CV) value of the second Delphi survey was below the CV value of the first Delphi survey and change in value of CV remained within a difference in value of 0.5 , no further Delphi surveys (after the second Delphi survey) 
were deemed necessary. Table 2 is to show the results of Delphi analysis.

Table 2. $1^{\text {st }}$ and $2^{\text {nd }}$ Round Delphi Results

\begin{tabular}{|c|c|c|c|c|c|c|c|c|c|}
\hline & \multirow[b]{2}{*}{$\begin{array}{l}\text { Competitiveness Assessment } \\
\text { Index }\end{array}$} & \multirow[b]{2}{*}{ Delphi } & \multicolumn{3}{|c|}{ Descriptive Statistics } & \multicolumn{3}{|c|}{ Convergence Tendency } & \multirow[b]{2}{*}{$\begin{array}{r}\text { Selection } \\
\text { Result }\end{array}$} \\
\hline & & & Average & $\begin{array}{l}\text { Standard } \\
\text { Deviation }\end{array}$ & $\begin{array}{l}\text { Positive } \\
\text { Rate }\end{array}$ & $\begin{array}{l}\text { Convergence } \\
\text { Level }\end{array}$ & $\begin{array}{l}\text { Agreement } \\
\text { Level }\end{array}$ & CVR & \\
\hline \multirow{12}{*}{$\begin{array}{l}\text { Factor } \\
\text { Conditions } \\
\text { (5 indices) } \\
\text { (Kendall's } \\
\mathrm{W}=0.297, y^{2} \\
=9.698, \mathrm{df}=5, \\
\mathrm{p}=0.000)\end{array}$} & \multirow{2}{*}{$\begin{array}{l}\text { Average length of instructors' } \\
\text { experience }\end{array}$} & $1^{\text {st }}$ & 3.74 & 0.915 & $73.9 \%$ & 0.50 & 0.75 & 0.478 & $\circ$ \\
\hline & & $2^{\text {nd }}$ & 3.80 & 0.616 & $70.0 \%$ & 0.50 & 0.75 & 0.40 & $\mathbf{x}$ \\
\hline & \multirow{2}{*}{$\begin{array}{l}\text { Quality of instructors of aviation } \\
\text { training organizations (Level of } \\
\text { satisfaction with instructors) }\end{array}$} & $1^{\text {st }}$ & 4.65 & 0.573 & $95.7 \%$ & 0.50 & 0.8 & 0.913 & $\circ$ \\
\hline & & $2^{\text {nd }}$ & 4.85 & 0.366 & $100 \%$ & 0.00 & 1.00 & 1.00 & - \\
\hline & \multirow{2}{*}{$\begin{array}{l}\text { Level of qualification training and } \\
\text { academic background of staff and } \\
\text { instructors }\end{array}$} & $1^{\mathrm{st}}$ & 4.22 & 0.671 & $87.0 \%$ & 0.50 & 0.75 & 0.739 & $\circ$ \\
\hline & & $2^{\text {nd }}$ & 4.35 & 0.489 & $100 \%$ & 0.50 & 0.75 & 1.00 & $\bullet$ \\
\hline & \multirow{2}{*}{$\begin{array}{l}\text { Convenience of facilities (e.g. } \\
\text { accommodation, cafeteria, sports } \\
\text { facilities) }\end{array}$} & $1^{\text {st }}$ & 4.13 & 0.548 & $91.3 \%$ & 0.00 & 1.00 & 0.826 & ० \\
\hline & & $2^{\text {nd }}$ & 4.30 & 0.571 & $95.0 \%$ & 0.50 & 0.75 & 0.90 & - \\
\hline & \multirow{2}{*}{$\begin{array}{l}\text { Level of training quality } \\
\text { management system (e.g. LMS, } \\
\text { Internal Quality Assurance } \\
\text { Program) }\end{array}$} & $1^{\mathrm{st}}$ & 4.43 & 0.590 & $95.7 \%$ & 0.50 & 0.75 & 0.913 & $\circ$ \\
\hline & & $2^{\text {nd }}$ & 4.40 & 0.598 & $95.0 \%$ & 0.50 & 0.75 & 0.90 & - \\
\hline & \multirow{2}{*}{$\begin{array}{l}\text { Personnel engagement and } \\
\text { commitment }\end{array}$} & $1^{\mathrm{st}}$ & \multicolumn{7}{|c|}{ Newly added } \\
\hline & & $2^{\text {nd }}$ & 4.55 & 0.510 & $100 \%$ & 0.50 & 0.80 & 1.00 & $\bullet$ \\
\hline \multicolumn{3}{|l|}{ Total Average } & 4.38 & 0.530 & $93.3 \%$ & 0.42 & 0.80 & 0.87 & - \\
\hline \multirow{8}{*}{$\begin{array}{l}\text { Demand } \\
\text { Conditions } \\
\text { (4 indices) }\end{array}$} & \multirow{2}{*}{$\begin{array}{l}\text { Number of overseas trainees in } \\
\text { aviation training organizations }\end{array}$} & $1^{\mathrm{st}}$ & 3.70 & 0.822 & $69.6 \%$ & 0.50 & 0.75 & 0.391 & $\circ$ \\
\hline & & $2^{\text {nd }}$ & 3.40 & 0.681 & $50.0 \%$ & 0.50 & 0.71 & $\mathbf{0 . 0 0}$ & $\mathbf{X}$ \\
\hline & \multirow{2}{*}{$\begin{array}{l}\text { Market size (Business market size / } \\
\text { markets available to firms) }\end{array}$} & $1^{\mathrm{st}}$ & 3.87 & 0.869 & $78.3 \%$ & 0.00 & 1.00 & 0.565 & $\circ$ \\
\hline & & $2^{\text {nd }}$ & 3.70 & 0.470 & $70.0 \%$ & 0.50 & 0.75 & 0.40 & $\mathbf{X}$ \\
\hline & \multirow{2}{*}{ Scale of aviation labor market } & $1^{\mathrm{st}}$ & 4.09 & 0.668 & $82.6 \%$ & 0.50 & 0.75 & 0.652 & $\circ$ \\
\hline & & $2^{\text {nd }}$ & 4.25 & 0.550 & $95.0 \%$ & 0.50 & 0.75 & 0.90 & - \\
\hline & \multirow{2}{*}{$\begin{array}{l}\text { Aviation industry growth rate in the } \\
\text { selected region } \\
\text { (e.g. Asia-Pacific, Europe) }\end{array}$} & $1^{\text {st }}$ & 4.09 & 0.596 & $87.0 \%$ & 0.00 & 1.00 & 0.739 & $\circ$ \\
\hline & & $2^{\text {nd }}$ & 4.15 & 0.489 & $95.0 \%$ & 0.00 & 1.00 & 0.90 & - \\
\hline \multirow{6}{*}{$\begin{array}{l}\text { (Kendall's } \\
\mathrm{W}=0.374, y^{2} \\
=44.851, \\
\mathrm{df}=6, \\
\mathrm{p}=0.000)\end{array}$} & \multirow{2}{*}{$\begin{array}{l}\text { Goods market efficiency (Customer } \\
\text { orientation, level of how demanding } \\
\text { customers are) / buyer } \\
\text { sophistication in the country }\end{array}$} & $1^{\mathrm{st}}$ & 3.87 & 0.920 & $73.9 \%$ & 0.50 & 0.75 & 0.478 & $\circ$ \\
\hline & & $2^{\text {nd }}$ & 3.85 & 0.745 & $65.0 \%$ & 0.50 & 0.75 & 0.30 & $\mathbf{X}$ \\
\hline & \multirow{2}{*}{$\begin{array}{l}\text { Number of trainees per one training } \\
\text { staff member }\end{array}$} & $1^{\mathrm{st}}$ & 3.78 & 0.850 & $69.6 \%$ & 0.50 & 0.75 & 0.391 & $\circ$ \\
\hline & & $2^{\text {nd }}$ & 4.20 & 0.616 & $90.0 \%$ & 0.50 & 0.75 & $\mathbf{0 . 8 0}$ & $\bullet$ \\
\hline & \multirow{2}{*}{$\begin{array}{l}\text { Feedback from trainees for the } \\
\text { course (Level of satisfaction with } \\
\text { the course) }\end{array}$} & $1^{\mathrm{st}}$ & 4.61 & 0.499 & $100 \%$ & 0.50 & 0.80 & 1.000 & $\circ$ \\
\hline & & $2^{\text {nd }}$ & 4.65 & 0.489 & $95.0 \%$ & 0.50 & 0.80 & 0.90 & $\bullet$ (SA) \\
\hline \multicolumn{3}{|l|}{ Total Average } & 4.03 & 0.58 & $80.0 \%$ & 0.43 & 0.79 & 0.60 & - \\
\hline
\end{tabular}

(continuous)

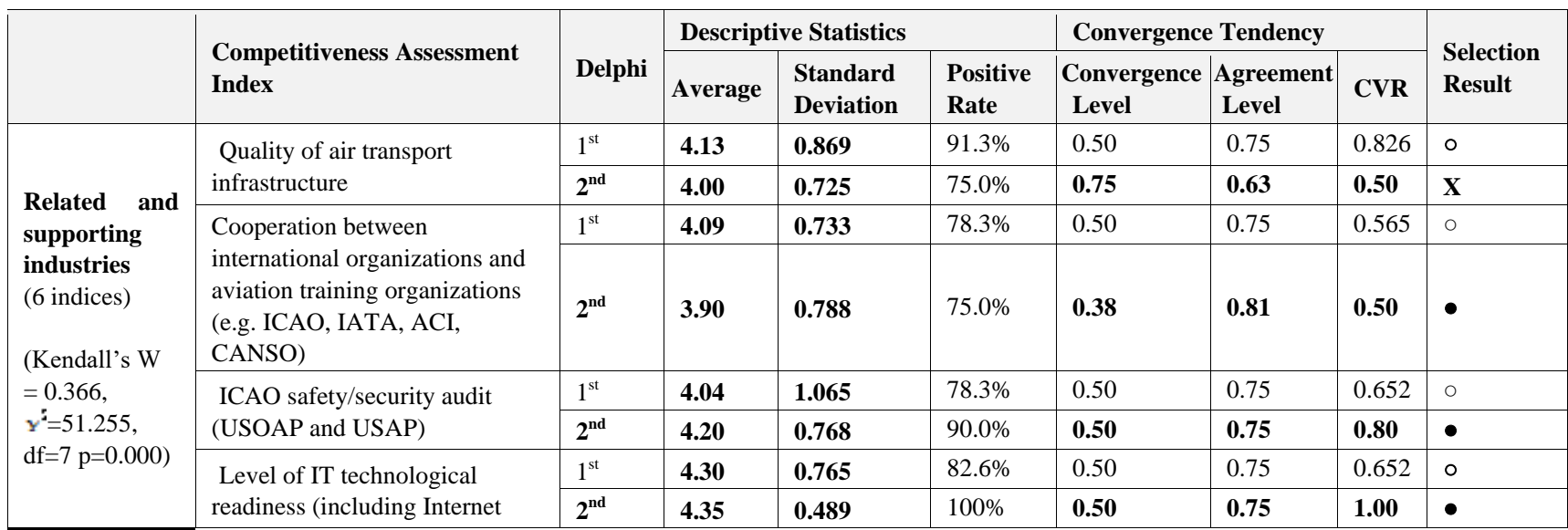




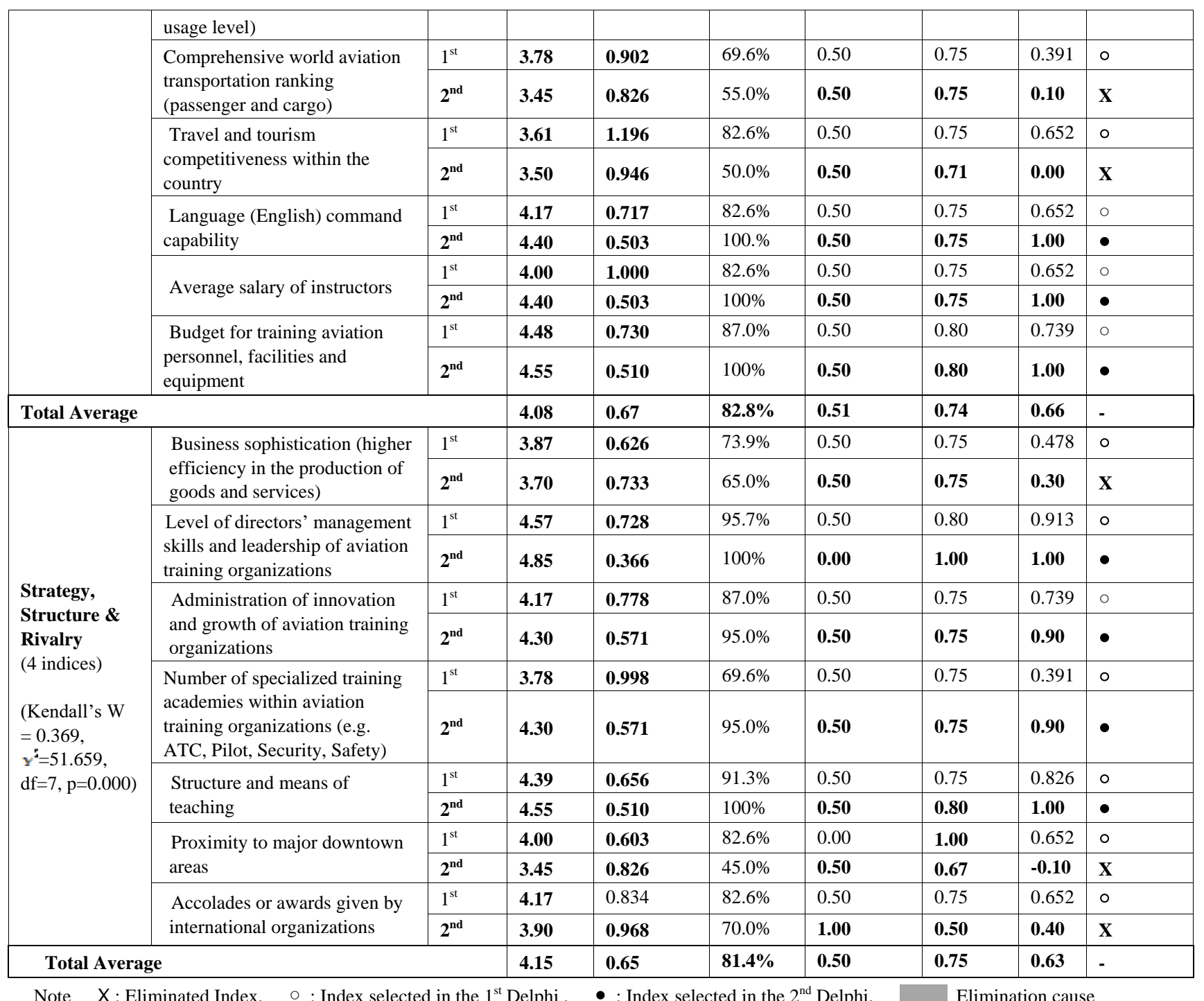

Note $\quad X$ : Eliminated Index, $\quad \circ$ : Index selected in the $1^{\text {st }}$ Delphi, $\quad \bullet:$ Index selected in the $2^{\text {nd }}$ Delphi, Elimination cause

The $1^{\text {st }}$ Delphi survey was carried out with open-ended and close-ended questionnaires. A total of 62 competitiveness assessment indices were assessed, with the aim of adding or amending other items not included in the original 62 indices. Six indices were moved or merged into other associated indices, four indices were amended, and one index was newly added. A total of 29 competitiveness assessment indices were finally selected as a result of the first Delphi survey.

These 29 indices were sorted out into a total of 19 indices through the second Delphi survey. Considering the number of panelists, the corresponding CVR values (first Delphi: 0.37, second Delphi: 0.42) were applied (Lawshe, 1975). The indices with values lower than the corresponding reference CVR values were eliminated. In addition, a positive response rate (i.e. indicating responses of 4 or 5 on the 5-point Likert scale) of over 55 percent was applied, with a convergence level of below 0.5 and an agreement level exceeding 0.75 .

The indices with average values over 3.56 applied in the first Delphi survey were selected as applicable indices for the competitiveness assessment of global aviation training organization. This proved that the panelists agreed relatively well with one another because the Kendall's W values ranged from 0.297 to 0.374 which is within the valid reference value in the second Delphi survey.

Among the 19 selected indices, 'Quality of instructors of aviation training organizations' and 'Level of directors' management skills and leadership of the training organizations' had the highest average values (4.85). These indices were followed by 'Feedback from trainees for the course (Level of satisfaction with the course)' with an average value of 4.65, suggesting that feedback from trainees indicating satisfaction with the training courses was also very significant. Next, 'Personnel engagement and commitment' had an average value of 4.55, indicating that the most vital elements for the competitiveness assessment of a global aviation training organization were human performance related items. 
Table 3. Empirical Study on Delphi Results

\begin{tabular}{|c|c|c|c|c|c|c|c|}
\hline Upper Class & Lower Class & Particular index & Average & $\begin{array}{l}\text { Standard } \\
\text { Deviation }\end{array}$ & CV & $\begin{array}{l}\text { Cronbach's } \\
\alpha \\
\text { after } \\
\text { removal }\end{array}$ & $\begin{array}{l}\text { Cronbach' } \\
\text { s } \alpha\end{array}$ \\
\hline \multirow{5}{*}{$\begin{array}{l}\text { Factor } \\
\text { conditions }\end{array}$} & \multirow{3}{*}{$\begin{array}{l}\text { Personnel } \\
\text { Organization }\end{array}$} & $\begin{array}{l}\text { Quality of instructors of aviation training } \\
\text { organizations (Level of satisfaction with } \\
\text { instructors) }\end{array}$ & 4.790 & 0.4094 & 0.09 & 0.942 & \multirow{3}{*}{0.736} \\
\hline & & $\begin{array}{l}\text { Level of qualification training and } \\
\text { academic } \\
\text { background of staff and instructors }\end{array}$ & 4.720 & 0.4513 & 0.10 & 0.942 & \\
\hline & & Personnel engagement and commitment & 4.720 & 0.4513 & 0.10 & 0.941 & \\
\hline & \multirow{2}{*}{$\begin{array}{l}\text { Training facility \& } \\
\text { System }\end{array}$} & $\begin{array}{l}\text { Convenience of facilities (e.g. classroom, } \\
\text { accommodation, cafeteria, sports facilities) } \\
\text { of aviation training organizations }\end{array}$ & 4.750 & 0.4352 & 0.09 & 0.940 & \multirow{2}{*}{$\mathbf{0 . 8 3 1}$} \\
\hline & & $\begin{array}{l}\text { Level of training quality management } \\
\text { system (e.g. LMS, Internal Quality } \\
\text { Assurance Program) }\end{array}$ & 4.740 & 0.4408 & 0.09 & 0.941 & \\
\hline \multirow{4}{*}{$\begin{array}{l}\text { Demand } \\
\text { conditions }\end{array}$} & \multirow{2}{*}{$\begin{array}{l}\text { Size of training } \\
\text { market }\end{array}$} & Scale of aviation labor market & 4.550 & 0.5389 & 0.12 & 0.941 & \multirow[b]{2}{*}{0.856} \\
\hline & & $\begin{array}{l}\text { Regional aviation industry growth rate } \\
\text { (e.g. Asia-Pacific, Europe) }\end{array}$ & 4.590 & 0.5143 & 0.11 & 0.940 & \\
\hline & \multirow{2}{*}{$\begin{array}{l}\text { Quality of training } \\
\text { market }\end{array}$} & $\begin{array}{l}\text { Number of trainees per one training staff } \\
\text { member }\end{array}$ & 4.640 & 0.4824 & 0.10 & 0.941 & \multirow{2}{*}{0.730} \\
\hline & & $\begin{array}{l}\text { Feedback from trainees for the course } \\
\text { (Level of satisfaction with the course) }\end{array}$ & 4.730 & 0.4462 & 0.09 & 0.940 & \\
\hline \multirow{6}{*}{$\begin{array}{l}\text { Related and } \\
\text { supporting } \\
\text { industries }\end{array}$} & \multirow{3}{*}{$\begin{array}{l}\text { Professional and } \\
\text { technical } \\
\text { support } \\
\text { environment }\end{array}$} & $\begin{array}{l}\text { Cooperation between international } \\
\text { organizations and aviation training } \\
\text { organizations } \\
\text { (e.g. ICAO, IATA, ACI, CANSO) }\end{array}$ & 4.740 & 0.5049 & 0.11 & 0.941 & \multirow{3}{*}{0.834} \\
\hline & & $\begin{array}{l}\text { ICAO safety/security audit (USOAP and } \\
\text { USAP) results in the country }\end{array}$ & 4.740 & 0.5049 & 0.11 & 0.940 & \\
\hline & & $\begin{array}{l}\text { Level of IT technological readiness } \\
\text { (including internet usage level) }\end{array}$ & 4.660 & 0.5360 & 0.12 & 0.940 & \\
\hline & \multirow{3}{*}{$\begin{array}{l}\text { inancial/general } \\
\text { upporting } \\
\text { pnditions }\end{array}$} & Language (English) command capability & 4.740 & 0.4845 & 0.10 & 0.943 & \multirow{3}{*}{0.719} \\
\hline & & Average salary of instructors & 4.520 & 0.5409 & 0.12 & 0.943 & \\
\hline & & $\begin{array}{l}\text { Budget for aviation personnel training, } \\
\text { facilities and equipment }\end{array}$ & 4.690 & 0.4648 & 0.10 & 0.940 & \\
\hline \multirow{4}{*}{$\begin{array}{l}\text { Firm strategy, } \\
\text { structure, } \\
\text { rivalry }\end{array}$} & \multirow{2}{*}{$\begin{array}{l}\text { Organization } \\
\text { strategy }\end{array}$} & $\begin{array}{l}\text { Level of director's management skills and } \\
\text { leadership of aviation training } \\
\text { organizations }\end{array}$ & 4.680 & 0.4688 & 0.10 & 0.941 & \multirow[t]{2}{*}{0.754} \\
\hline & & $\begin{array}{l}\text { Administration of innovation and growth } \\
\text { of aviation training organizations }\end{array}$ & 4.680 & 0.4899 & 0.10 & 0.940 & \\
\hline & \multirow{2}{*}{$\begin{array}{l}\text { Structure of } \\
\text { training } \\
\text { organization }\end{array}$} & $\begin{array}{l}\text { Number of specialized training academies } \\
\text { within aviation training organizations } \\
\text { (e.g. ATC, Pilot, Security, Safety) }\end{array}$ & 4.670 & 0.5329 & 0.11 & 0.940 & \multirow[t]{2}{*}{0.756} \\
\hline & & Structure and means for teaching & 4.760 & 0.4292 & 0.09 & 0.940 & \\
\hline
\end{tabular}

In accordance with the empirical analysis, as Table 3 illustrates, all 19 competitiveness assessment indices were verified as justifiable (with average values of over 4.2) as competitiveness assessment indices. The analysis also proved that all indices were stable with CV values under 0.12.

\section{AHP Analysis and Structure of Assessment Indices}

The AHP analysis was conducted with the 19 indices selected from the Delphi survey through 162 participants (22 aviation training experts and 140 general trainees). Some responses from general trainees were eliminated because the CR values were not satisfactory.

The decision making hierarchy structure was organized for an AHP survey with three classes (upper, lower and particular indices) as shown in Fig. 2 On the basis of the triple-class hierarchy structure, a total of 24 questionnaire 
items regarding the 19 indices was drafted. Each questionnaire item was designed to analyze the relative importance level (weight) of the upper and lower class items as well as the particular indices based on a 9-point Likert scale.

The results of the importance level (weight) for each upper class item are illustrated in Table 4. 'Factor conditions' (0.297) was ranked first, followed by 'Demand conditions' (0.253), 'Strategy, Structure and rivalry' $(0.227)$ and 'Related and supporting industries' (0.224). The analysis showed that the importance level (weight) of each upper class item was evenly distributed.

The CR values of each panelist for the relative importance assessment of each upper class item were within 0.100, meaning the consistency of each item was satisfactory.

Table 5 illustrates the relative importance and the priority ranking of each lower class item, and the comprehensive analysis results of the importance level (weight) of each index and class item (i.e. upper class, lower class and particular indices) are illustrated in Fig. 2.

Table 4. Numerical Weight and Priority of Upper Level

\begin{tabular}{l|l|l|l|l|l|l}
\hline \multirow{2}{*}{ Upper Class Item } & \multicolumn{2}{l}{ Results } & \multicolumn{2}{l}{ Panelists } & \multicolumn{2}{l}{ General Trainees } \\
\cline { 2 - 8 } & $\begin{array}{l}\text { Relative } \\
\text { Importance }\end{array}$ & $\begin{array}{l}\text { Priority } \\
\text { Ranking }\end{array}$ & $\begin{array}{l}\text { Relative } \\
\text { Importance }\end{array}$ & $\begin{array}{l}\text { Priority } \\
\text { Ranking }\end{array}$ & $\begin{array}{l}\text { Relative } \\
\text { Importance }\end{array}$ & $\begin{array}{l}\text { Priority } \\
\text { Ranking }\end{array}$ \\
\hline Factor conditions & 0.296 & 1 & $\mathbf{0 . 3 6 9}$ & $\mathbf{1}$ & $\mathbf{0 . 2 8 3}$ & $\mathbf{1}$ \\
\hline Demand conditions & 0.253 & 2 & 0.176 & 4 & $\mathbf{0 . 2 6 8}$ & $\mathbf{2}$ \\
\hline Related and supporting industries & 0.224 & 4 & $\mathbf{0 . 2 7 1}$ & $\mathbf{2}$ & 0.215 & 4 \\
\hline Strategy, structure and rivalry & 0.227 & 3 & 0.184 & 3 & 0.234 & 3 \\
\hline CR & 0.000 & & 0.001 & & 0.001 & \\
\hline
\end{tabular}

Table 5. Numerical Weight and Priority of Lower Level

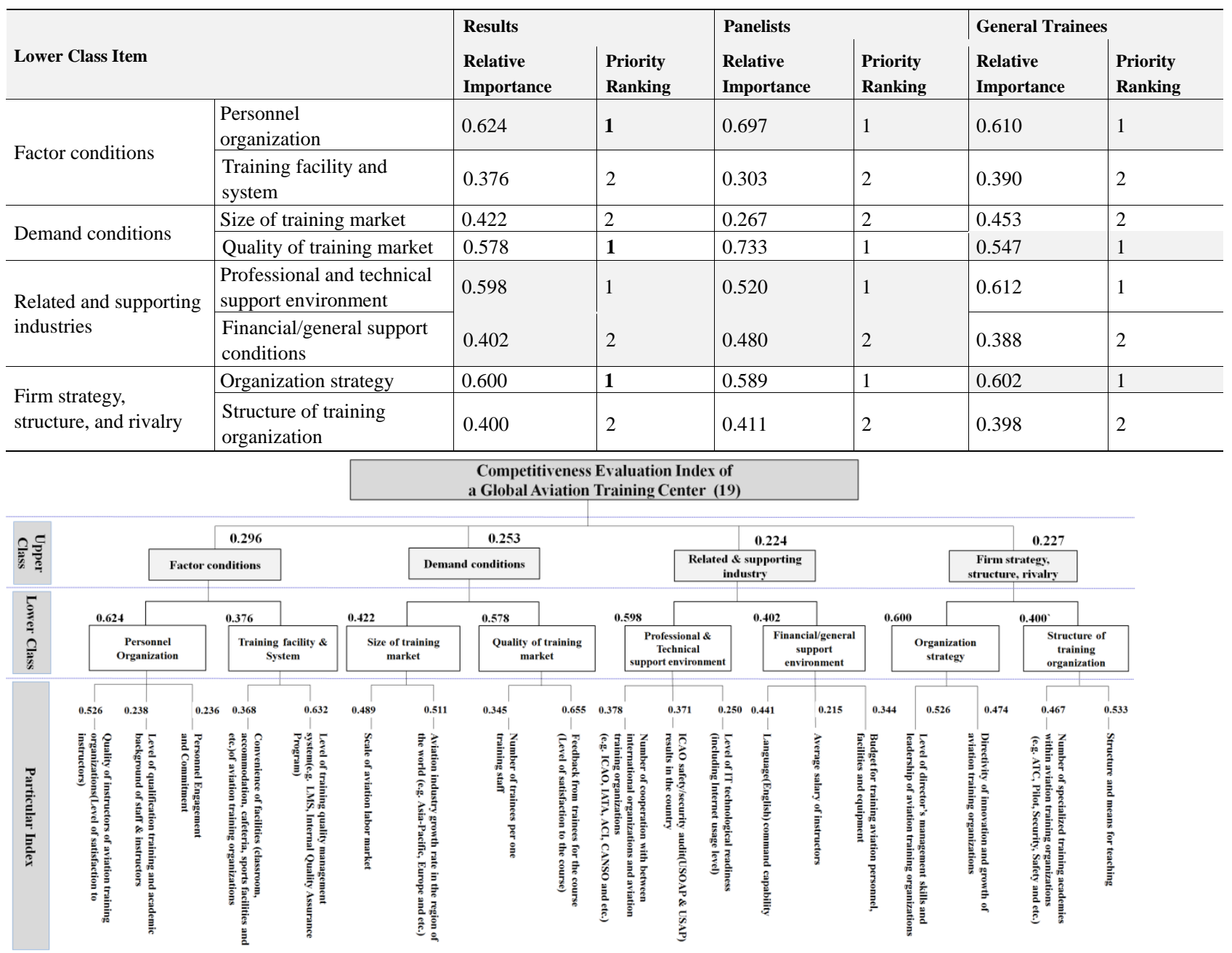

Figure 2. Weighted Value Hierarchy of Competitiveness Evaluation Index

Out of a total of 19 indices for competitiveness assessment of global aviation training organizations, the highest weight 
was given to 'Quality of instructors of aviation training organizations (Level of satisfaction with instructors)' $(0.097)$ and the lowest weight (significance level) was given to 'Average salary of instructors' (0.019). Detailed analysis results are illustrated in Table 6.

Table 6. Final Competiveness Index and Numerical Weight

\begin{tabular}{|c|c|c|c|c|}
\hline Upper Class & Lower Class & Particular Index & $\begin{array}{l}\text { Weight } \\
\text { (Significance } \\
\text { Level) }\end{array}$ & Priority \\
\hline (a) & (b) & (c) & $(a \times b \times c)$ & \\
\hline \multirow{5}{*}{ Factor conditions } & \multirow{3}{*}{$\begin{array}{l}\text { Personnel } \\
\text { organization }\end{array}$} & $\begin{array}{l}\text { Quality of instructors of aviation training organizations (Level of } \\
\text { satisfaction with instructors) }\end{array}$ & 0.097 & 1 \\
\hline & & $\begin{array}{l}\text { Level of training qualification and academic } \\
\text { background of staff and instructors }\end{array}$ & 0.044 & 12 \\
\hline & & Personnel engagement and commitment & 0.044 & 13 \\
\hline & \multirow{2}{*}{ Training facility and system } & $\begin{array}{l}\text { Convenience of facilities (e.g. classroom, accommodation, } \\
\text { cafeteria, sports facilities) of aviation training organizations }\end{array}$ & 0.041 & 15 \\
\hline & & $\begin{array}{l}\text { Level of training quality management system (e.g. LMS, } \\
\text { Internal Quality Assurance Program) }\end{array}$ & 0.070 & 4 \\
\hline \multirow{4}{*}{ Demand conditions } & \multirow[b]{2}{*}{ Size of training market } & Scale of aviation labor market & 0.052 & 7 \\
\hline & & $\begin{array}{l}\text { Regional aviation industry growth rate in the (e.g. Asia-Pacific, } \\
\text { Europe) }\end{array}$ & 0.054 & 6 \\
\hline & \multirow[b]{2}{*}{ Quality of training market } & Number of trainees per one training staff member & 0.050 & 9 \\
\hline & & $\begin{array}{l}\text { Feedback from trainees for the course } \\
\text { (Level of satisfaction with the course) }\end{array}$ & 0.096 & 2 \\
\hline \multirow{6}{*}{$\begin{array}{l}\text { Related and } \\
\text { supporting industries }\end{array}$} & \multirow{3}{*}{$\begin{array}{l}\text { Professional and technical } \\
\text { support environment }\end{array}$} & $\begin{array}{l}\text { Cooperation between international organizations and aviation } \\
\text { training organizations (e.g. ICAO, IATA, ACI, CANSO) }\end{array}$ & 0.051 & 8 \\
\hline & & $\begin{array}{l}\text { ICAO safety/security audit (USOAP and USAP) results in the } \\
\text { country }\end{array}$ & 0.050 & 10 \\
\hline & & $\begin{array}{l}\text { Level of IT technological readiness } \\
\text { (including Internet usage level) }\end{array}$ & 0.034 & 17 \\
\hline & \multirow{3}{*}{$\begin{array}{l}\text { Financial/general support } \\
\text { conditions }\end{array}$} & Language (English) command capability & 0.040 & 16 \\
\hline & & Average salary of instructors & 0.019 & 19 \\
\hline & & Budget for training aviation personnel, facilities and equipment & 0.031 & 18 \\
\hline \multirow{4}{*}{$\begin{array}{l}\text { Firm strategy, } \\
\text { structure, rivalry }\end{array}$} & \multirow{2}{*}{ Organization strategy } & $\begin{array}{l}\text { Level of directors' management skills and leadership of aviation } \\
\text { training organizations }\end{array}$ & 0.072 & 3 \\
\hline & & $\begin{array}{l}\text { Administration of innovation and growth of aviation training } \\
\text { organizations }\end{array}$ & 0.065 & 5 \\
\hline & \multirow[t]{2}{*}{$\begin{array}{l}\text { Structure of training } \\
\text { organization }\end{array}$} & $\begin{array}{l}\text { Number of specialized training academies within aviation training } \\
\text { organizations (e.g. ATC, Pilot, Security, Safety) }\end{array}$ & 0.042 & 14 \\
\hline & & Structure and means for teaching & 0.048 & 11 \\
\hline
\end{tabular}

The differences between the panelists' group and general trainees' group are illustrated in Table 7. The panelists assessed the weight of each particular index in the following order: 'Quality of instructors' $(0.141)$, 'Feedback from trainees for the course' (0.096), 'Level of directors' management skills and leadership of aviation training organizations' (0.073), 'Level of training quality management system(0.072) and so on. Meanwhile, the general trainees assessed the weight of each particular index in the following order: 'Feedback from trainees for the course (Level of satisfaction with the course)' (0.096), 'Quality of instructors' (0.090), 'Administration of innovation and growth of aviation training organizations' (0.071), 'Level of directors' management skills and leadership of aviation training organizations' $(0.070)$ and so on. 
Table 7. Final Competiveness Index and Numerical Weight of Experts and Trainees

\begin{tabular}{|c|c|c|c|c|c|c|}
\hline \multirow{2}{*}{ Particular index } & \multicolumn{2}{|c|}{ Panelist (a) } & \multicolumn{2}{|c|}{ General Trainee (b) } & \multicolumn{2}{|c|}{$\begin{array}{l}\text { Gap between both } \\
\text { groups (a-b) }\end{array}$} \\
\hline & Weight & Rank & Weight & Rank & Weight & Rank \\
\hline $\begin{array}{l}\text { Quality of instructors of aviation training organizations (Level of } \\
\text { satisfaction with instructors) }\end{array}$ & 0.141 & 1 & 0.090 & 2 & 0.051 & -1 \\
\hline $\begin{array}{l}\text { Level of training qualification and academic } \\
\text { background of staff and instructors }\end{array}$ & 0.057 & 6 & 0.042 & 13 & 0.015 & -7 \\
\hline Personnel engagement and commitment & 0.059 & 5 & 0.041 & 14 & 0.018 & -9 \\
\hline $\begin{array}{l}\text { Convenience of facilities (e.g. classroom, accommodation, cafeteria, } \\
\text { sports facilities) of aviation training organizations }\end{array}$ & 0.040 & 12 & 0.041 & 15 & -0.001 & -3 \\
\hline $\begin{array}{l}\text { Level of training quality management system (e.g. LMS, Internal } \\
\text { Quality Assurance Program) }\end{array}$ & 0.072 & 4 & 0.069 & 5 & 0.003 & -1 \\
\hline Scale of aviation labor market & 0.022 & 19 & 0.060 & 7 & -0.038 & 12 \\
\hline Regional Aviation industry growth rate (e.g. Asia-Pacific, Europe) & 0.025 & 18 & 0.061 & 6 & -0.036 & 12 \\
\hline Number of trainees per one training staff member & 0.033 & 16 & 0.053 & 8 & -0.02 & 8 \\
\hline $\begin{array}{l}\text { Feedback from trainees for the course } \\
\text { (Level of satisfaction with the course) }\end{array}$ & 0.096 & 2 & 0.093 & 1 & 0.003 & 1 \\
\hline $\begin{array}{l}\text { Cooperation between international organizations and aviation training } \\
\text { organizations (e.g. ICAO, IATA, ACI, CANSO) }\end{array}$ & 0.052 & 7 & 0.050 & 11 & 0.002 & -4 \\
\hline ICAO safety/security audit (USOAP and USAP) results of the country & 0.044 & 11 & 0.050 & 9 & -0.006 & 2 \\
\hline Level of IT technological readiness (including Internet usage level) & 0.045 & 10 & 0.031 & 17 & 0.014 & -7 \\
\hline Language (English) command capability & 0.050 & 8 & 0.038 & 16 & 0.012 & -8 \\
\hline Average salary of instructors & 0.031 & 17 & 0.018 & 19 & 0.013 & -2 \\
\hline Budget for aviation personnel training, facilities and equipment & 0.049 & 9 & 0.028 & 18 & 0.021 & -9 \\
\hline $\begin{array}{l}\text { Level of directors' management skills and leadership of aviation } \\
\text { training organizations }\end{array}$ & 0.073 & 3 & 0.070 & 4 & 0.003 & -1 \\
\hline $\begin{array}{l}\text { Administration of innovation and growth of aviation training } \\
\text { organizations }\end{array}$ & 0.035 & 15 & 0.071 & 3 & -0.036 & 12 \\
\hline $\begin{array}{l}\text { Number of specialized training academies within aviation training } \\
\text { organizations } \\
\text { (e.g. ATC, Pilot, Security, Safety) }\end{array}$ & 0.038 & 14 & 0.043 & 12 & -0.005 & 2 \\
\hline Structure and means for teaching & 0.038 & 13 & 0.050 & 10 & -0.012 & $\beta$ \\
\hline
\end{tabular}

The level of gaps in weights between the two groups were demonstrated in the following order: 'Scale of aviation labor market' (Gap value: 0.038), 'Regional aviation industry growth rate (e.g. Asia-Pacific, Europe)' (Gap value: 0.036) and 'Administration of innovation and growth of aviation training organizations' (Gap value: 0.036).

The trainee group put the highest value on the items associated with the training market, while the panelist group, as training suppliers, thought of the training market the least important area. Among the 19 indices, 10 indices showed ranking differences between 1 to 4 , six indices indicated a ranking difference between 7 to 9 , and three indices showed 12 ranking differences. However, it appeared that the gap difference between the panelist group and the general trainee group was not big.

\section{Conclusion}

This study was carried out in order to finalize the competitiveness assessment indices of global aviation training organizations through Delphi surveys and an AHP survey by expert panelists. All indices were classified into four categories (Upper class at AHP structure) based on Diamond theory.

The AHP analysis results revealed that among the 19 indices for the competitiveness assessment of global aviation training organizations, 'Quality of instructors' $(0.097)$ and 'Feedback from trainees' $(0.096)$ were selected as the most significant indices. The third most important index was 'Level of director's management skills and leadership of aviation training organizations'(0.073).

This study provided a meaningful opportunity to study competitiveness assessment for global aviation training organizations and opened up opportunities to connect strategies of global aviation training organizations with business strategy research.

\section{References}

Best, R. J. (1974). An experiment in Delphi estimation in marketing decision making. Journal of Marketing Research, 11(4), 448-452. https://doi.org/10.2307/3151295

Cho, G. T., Cho, Y. G., \& Kang, H. S. (2013). Analytic Hierarchy Decision Making of Advanced Leaders. Seoul: Dong Hyun Press 
Choi, H. S. C., \& Sirakaya, E. (2006). Sustainability indicators for managing community tourism, Tourism Management, 27(6), 1274 -1289. https://doi.org/10.1016/j.tourman.2005.05.018

Chung Yoon, et al, (2013). Study on international competitiveness analysis on Medicare Tourism: Focusing on Korea, Thailand, Singapore and Malaysia”, Korea Institute for Industrial Economic \& Trade.

Donohoe, H. M., \& Needham, R. D. (2008). Moving best practice forward: Delphi characteristics, advantages, potential problems, and solutions," International Journal of Tourism Research, 11(5), 415-437.

Donohoe, H. M., \& Needham, R. D. (2008). Moving best practice forward: Delphi characteristics, advantages, potential problems, and solutions. International Journal of Tourism Research, 11(5), 415-437. https://doi.org/10.1002/jtr.709

Kim, Y. J. (2013). Hierarchy Strategic Assessment Model Development and Major Element Significance Level Analysis - focusing on Incheon Airport, Cheung Buk University

Kwon, T. I. (2009). Study on priority of affected factors in tourist attraction remodeling: Application on Delphi and AHP method, Sejong University

Lawshe, C. H. (1975). A quantitative approach to content validity, Personnel Psychology, 28, 563-575. Purdue University

Lee, H. J. (2011). Assessment Indicator Development for Secretary Major in Specialized Colleges, Seoul National University

Porter, M. E. (1980). Competitive Strategy, Free Press, New York

Rowe, G., \& Wright, G. (2001). Expert opinions in forecasting: The role of the Delphi technique in J. Armstrong (Ed.) Principles of Forecasting, Boston: Kluwer Academic, 125-144. https://doi.org/10.1007/978-0-306-47630-3_7

Saaty, T. L. (1980). The Analytic Hierarchy Process," McGraw-Hill, New York.

Seo, I. Y. (2008). Study on standards and Indicators for University Competitiveness Assessment, Chung-Ang University

Song, D. Y. (2007). Specialized high school assessment standard development, Seoul National University

\section{Copyrights}

Copyright for this article is retained by the author(s), with first publication rights granted to the journal.

This is an open-access article distributed under the terms and conditions of the Creative Commons Attribution license which permits unrestricted use, distribution, and reproduction in any medium, provided the original work is properly cited. 